\title{
Cloning and Expression of the Tyrosinase Gene from Streptomyces antibioticus in Streptomyces lividans
}

\author{
By EDWARD KATZ, $\dagger$ CHARLES J. THOMPSON $\ddagger$ AND \\ DAVID A. HOPWOOD* \\ John Innes Institute, Colney Lane, Norwich NR4 7UH, U.K.
}

(Received 26 April 1983)

\begin{abstract}
In two separate studies a $B c l$ I-generated DNA fragment coding for the enzyme tyrosinase, responsible for melanin synthesis, was cloned from Streptomyces antibioticus DNA into two SLP1.2-based plasmid vectors (pIJ37 and pIJ41) to generate the hybrid plasmids, designated pIJ700 and pIJ701, using S. lividans 66 as the host. The fragment $(1.55 \mathrm{~kb})$ was subcloned into the multicopy plasmid pIJ350 (which carries thiostrepton resistance and has two non-essential $B c l$ sites) to generate four new plasmids (pIJ702-pIJ705) with the tyrosinase insert located in either orientation at each site. All six plasmids conferred melanin production (the $\mathrm{Mel}^{+}$ phenotype) on their host. As in the $S$. antibioticus parent, strains of $S$. lividans carrying the gene specifying tyrosinase synthesis possessed an enzyme activity which was inducible. Most of the tyrosinase activity was secreted during growth of $S$. antibioticus; in contrast, the majority remained intracellular in the $S$. lividans clones. The specific activity of the induced tyrosinase activity (intracellular) was higher (up to 36-fold) when the gene was present on the multicopy vector in comparison with its location on the low copy plasmids, pIJ700 or pIJ701, or in $S$. antibioticus.

Restriction mapping of the tyrosinase fragment in pIJ702 revealed endonuclease cleavage sites for several enzymes, including single sites for $B g l \mathrm{II}, S p h \mathrm{I}$ and $S s t \mathrm{I}$ that are absent from the parent vector (pIJ350). Insertion of DNA fragments at any one of these sites abolished the $\mathrm{Mel}^{+}$ phenotype. The results indicate that pIJ702 is a useful cloning vector with insertional inactivation of the $\mathrm{Mel}^{+}$character as the basis of clone recognition.
\end{abstract}

\section{INTRODUCTION}

The ability to synthesize melanin or melanin-like pigments is a common property among streptomycetes (Küster, 1976); moreover, similar pigments are produced by fungi (Fling et al., 1963; Bouchilloux et al., 1963; Bull \& Carter, 1973), unicellular bacteria (Pomerantz \& Murthy, 1974), plants (Robb et al., 1965; Vaughan \& Butt, 1970), insects (Karlson et al., 1964; Nakamura \& Sho, 1964) and mammalian cells (Pomerantz, 1963; Burnett, 1971). Melanin formation from tyrosine is due to the catalytic activity of the enzyme tyrosinase (EC 1.14.18.1), which has been purified to homogeneity from various sources (Fling et al., 1963; Bouchilloux et al., 1963; Vaughan \& Butt, 1970; Burnett, 1971; Lerch \& Ettlinger, 1972; Bull \& Carter, 1973; Pomerantz \& Murthy, 1974).

In Streptomyces, tyrosinase has interesting genetic determination and regulation. For example, studies with Streptomyces glaucescens have revealed that the enzyme is inducible by different amino acids, is synthesized intracellularly and is then secreted into the culture medium (Baumann \& Kocher, 1976; Baumann et al., 1976; Kieser et al., 1981). It has been reported that

$\dagger$ Present address: Department of Microbiology, Georgetown University Schools of Medicine and Dentistry, 3900 Reservoir Road, N.W., Washington, D.C. 20007, U.S.A.

$\$$ Present address: Biogen, S.A., Carouge, Geneva, Switzerland. 
the intracellular and extracellular forms of tyrosinase (S. glaucescens) are identical in molecular weight, copper content, the sequence of the first 19 amino acids at the $N$-terminal end and the ratio of cresolase to catecholase activity (Crameri et al., 1982). Mutants (structural, regulatory, constitutive, secretion-negative) have been isolated (Baumann \& Kocher, 1976; Baumann et al., 1976; Kieser et al., 1981), but little detailed information is available concerning the synthesis and translocation of tyrosinase activity. In many strains melanin production is an unstable property, indicating involvement of a special class of genetic element - either chromosomal as in $S$. glaucescens (Crameri et al., 1982) or possibily plasmid-borne as reported with $S$. scabies (Gregory \& Shyu, 1961; Gregory \& Huang, 1964). Questions remain regarding the location of the genetic determinants for tyrosinase synthesis and secretion.

Efficient interspecific cloning systems are available for use in Streptomyces. Thus, Bibb et al. (1980) cloned a methylenomycin resistance gene from $S$. coelicolor DNA and our laboratory has described the cloning of several antibiotic (neomycin, thiostrepton, viomycin, erythromycin) resistance determinants and nutritional genes in SLP1.2 and SCP2 derivatives employing PEGassisted transformation and transfection in S. lividans 66 (Suarez \& Chater, 1980; Thompson et al. 1980, 1982a).

The experiments reported here describe the cloning of a DNA fragment containing the tyrosinase gene from $S$. antibioticus into the Streptomyces plasmid vectors, pIJ37 and pIJ41. Preliminary structural and biochemical characterization of the clones and use of the tyrosinase gene in vector construction are also presented.

\section{METHODS}

Media. Most of the media have been described previously; glucose-yeast extract medium (GYM) (Lerch \& Ettlinger, 1972); yeast extract-malt extract plus 34\% (w/v) sucrose (YEME) (Bibb et al., 1977); R2YE medium (Thompson et al., 1980); P medium (Okanishi et al., 1974) and a modification (MMT) of the minimal medium (MM) described by Hopwood (1967). GYM was employed with D-glucose, $0.4 \%$ plus $\mathrm{CuSO}_{4} .5 \mathrm{H}_{2} \mathrm{O}, 0.00025 \%$; MMT (200 ml) for tyrosinase expression was minimal medium with $4 \mathrm{ml} \mathrm{Difco} \mathrm{Casamino} \mathrm{acids}(30 \%, \mathrm{w} / \mathrm{v}) ; 1.5 \mathrm{ml}$ of a solution containing $1 \% \mathrm{~L}$-histidine; $0.75 \%$ each of L-arginine, L-cystine, L-leucine, L-methionine, Lhomoserine, L-phenylalanine, L-proline; $0.15 \%$ each of adenine and uracil; $0.01 \%$ each of nicotinamide and thiamin, $10 \mathrm{ml}$ of an L-tyrosine solution $\left(7.5 \mathrm{mg} \mathrm{ml}^{-1}\right)$ and $1.5 \%$ Bacto agar. Tryptone Soya Broth (TNB) was obtained from Oxoid. T and L media have been described elsewhere (Thompson et al., 1982a).

For the selection of antibiotic-resistant strains, MMT contained neomycin sulphate (Sigma), $1 \mu \mathrm{g} \mathrm{ml}^{-1}$ or thiostrepton, $50 \mu \mathrm{g} \mathrm{ml}^{-1}$. Thiostrepton was kindly provided by $\mathrm{Mr}$ S. J. Lucania of E. J. Squibb and Sons, New Brunswick, N.J., U.S.A.; a stock solution containing $50 \mathrm{mg} \mathrm{ml}^{-1}$ in dimethylsulphoxide was added to the molten agar medium. Neomycin sulphate solutions were filter sterilized.

Bacterial strains. The recipient organisms used as hosts for recombinant plasmids were the following wild-type strains or mutants derived from them: S. lividans 66 (JII strain number 1326); S. coelicolor A3(2); S. griseus CUB 94; S. parvulus ATCC 12434; S. acrimycini IPV 1610; S. albus G; S. vinaceus NCIB 8852 and S. clavuligerus ATCC 27064. Donor organisms were $S$. antibioticus IMRU 3720 and $S$. griseus IMRU 3570.

DNA preparations. Total DNA was isolated from mycelium using the procedure described by Chater $e t$ al. (1982). Large-scale plasmid isolation was by the method of Bibb et al. (1977). Plasmid DNA was prepared on a small scale by an alkaline lysis procedure using a modification (Chater $e t$ al., 1982) of the method of Birnboim \& Doly (1979).

Restriction endonuclease digestions, agarose and polyacrylamide gel electrophoresis. These were carried out as described by Thompson et al. (1982b). Restriction endonucleases were purchased from BRL or BoeringerMannheim. Reaction mixtures $(20 \mu 1)$ generally contained $10 \mathrm{mM}-\mathrm{Tris} / \mathrm{HCl}, \mathrm{pH} 7 \cdot 4,10 \mathrm{mM}-\mathrm{MgCl}_{2}, 50 \mathrm{~mm}-\mathrm{NaCl}$, $1 \mathrm{mM}$-mercaptoethanol and DNA. Incubations for $4 \mathrm{~h}$ at $37^{\circ} \mathrm{C}\left(B c / \mathrm{I}, 55^{\circ} \mathrm{C}\right)$, were initiated by addition of the restriction endonuclease. Reactions were usually terminated by heating at $70^{\circ} \mathrm{C}$ for $10 \mathrm{~min} ; B c I$ digestions were terminated by precipitation with ethanol $\left(-20^{\circ} \mathrm{C}\right)$ or by addition of $0 \cdot 1 \%(\mathrm{v} / \mathrm{v})$ diethyl pyrocarbonate. Fragment sizes were measured by means of a Houston digitizer (Houston Instruments, Austin, Tex., U.S.A.) connected to an Apple II computer, using HindIII fragments of bacteriophage lambda DNA as molecular weight standards (Kieser, 1982).

Preparation and transformation of protoplasts. These were carried out essentially as described by Thompson et al. (1982a).

Shotgun cloning experiments. Bcll-digested total DNA of S. antibioticus was ligated with BclI-cleaved pIJ37 or Bam HI-digested pIJ41, using standard recombinant DNA techniques (digestions and ligations were monitored by agarose gel electrophoresis). Details of the procedure have been reported elsewhere (Thompson $e t$ al., 1982a). 
Ligated DNA was used to transform protoplasts $\left(3-4 \times 10^{9}\right)$ of S. lividans 1326 which were regenerated on R2YE plates and then replicated to MMT containing either neomycin or thiostrepton.

Matings. Spore suspensions of donor S. lividans 3129 (pIJ700, $\mathrm{Neo}^{\mathrm{R}}, \mathrm{Mel}^{+}$) or S. lividans 3130 (pIJ701, Thio ${ }^{\mathrm{R}}$, $\mathrm{Mel}^{+}$) and recipient $S$. lividans TK64 (pro-2, str-6) were mixed on slants of R2YE (Hopwood, 1967). After 6-9 d, spores were scraped from the slant, filtered through cotton plugs and plated under selective conditions on appropriately supplemented $\mathbf{M M}$.

Enzyme assays. Streptomyces antibioticus or S. lividans was cultivated in GYM liquid ( $25 \mathrm{ml}$ per $250 \mathrm{ml}$ flask) medium (Lerch \& Ettlinger, 1972) at $30^{\circ} \mathrm{C}$ on a rotary shaker (model G25, New Brunswick). Induction of tyrosinase activity was by addition of Bacto tryptose $\left(10 \mathrm{mg} \mathrm{ml}^{-1}\right.$, final concentration) and $\mathrm{CuSO}_{4} \cdot 5 \mathrm{H}_{2} \mathrm{O}$ $\left(5 \mu \mathrm{g} \mathrm{ml}^{-1}\right.$, final concentration) to rapidly-growing cultures of $S$. antibioticus (22-24 h) or S. lividans $(36-38 \mathrm{~h})$. Mycelium, collected by suction filtration on Whatman no. 2 paper using a Buchner funnel, was washed twice with $25 \mathrm{ml}$ cold sodium phosphate buffer $\left(0.05 \mathrm{M}, \mathrm{pH} \mathrm{7.2)}\right.$ and stored at $-20^{\circ} \mathrm{C}$ prior to use. Mycelium was disrupted in the same buffer by ultrasonic treatment (Dawes soniprobe; Dawes Instruments, London, U.K.) or passage twice through a French pressure cell (Aminco Instrument Co., Urbana, Ill., U.S.A.). After centrifugation at 12000 r.p.m. to remove intact cells and cellular debris, the supernatant was decanted and used as the source of intracellular enzyme. Extracellular tyrosinase activity was examined employing the culture filtrate.

Tyrosinase activity was measured using the dopachrome assay procedure (Lerch \& Ettlinger, 1972) with Ldihydroxyphenylalanine (L-DOPA) as substrate. L-DOPA $(10 \mu \mathrm{mol})$ in sodium phosphate buffer $(0 \cdot 1 \mathrm{M}, \mathrm{pH} 6 \cdot 0)$, additional buffer and enzyme in a total volume of $1 \cdot 1 \mathrm{ml}$ was incubated at $30^{\circ} \mathrm{C}$; formation of dopachrome was monitored continuously by measuring the increase in absorbance at $475 \mathrm{~nm}$, using a Gilford recording spectrophotometer (Oberlin, Ohio, U.S.A.). One unit of enzyme activity is the amount of enzyme that catalyses the oxidation of $1 \mu \mathrm{mol} \mathrm{L}$-DOPA per min. The molecular extinction coefficient for the reaction at $475 \mathrm{~nm}$ is 3600 . Specific activity is the number of enzyme units per $\mathrm{mg}$ of protein.

Protein. This was determined by the Lowry method using crystalline bovine serum albumin as standard.

Hybridization studies. ${ }^{32}$ P-labelled plasmid DNA or DNA fragments were prepared according to the procedure of Rigby et al. (1977). DNA fragments separated by agarose gel electrophoresis (Tris/acetate/EDTA buffer, pH 8.3) were denatured in alkali, neutralized and transferred to nitrocellulose filters, using the Southern blotting technique (Southern, 1975). Filters were preincubated for $6 \mathrm{~h}$ at $68^{\circ} \mathrm{C}$ in $6 \times$ standard saline citrate (SSC), $1 \times$ Denhardt's solution (Denhardt, 1966) and salmon sperm DNA $\left(50 \mu \mathrm{g} \mathrm{ml}^{-1}\right)$. Hybridizations were performed in small plastic tubes $(4.5 \mathrm{ml})$. The hybridization mixtures contained $2 \times \mathrm{SSC}, 1 \times$ Denhardt's solution, $0 \cdot 1 \%$ SDS, $1 \mathrm{~mm}$-EDTA (pH 7.5), $50 \mu \mathrm{g}$ sheared, denatured salmon sperm DNA ml ${ }^{-1}$ and about $0.01 \mu \mathrm{g}{ }^{32} \mathrm{P}$-labelled DNA $\mathrm{ml}^{-1}\left(1-5 \times 10^{6} \mathrm{c} . \mathrm{p} . \mathrm{m}\right.$.). Prior to hybridization, the DNA was denatured by boiling for $10 \mathrm{~min}$. After hybridization at $68^{\circ} \mathrm{C}$ for $24 \mathrm{~h}$, the filters were washed 10 times in $2 \times \mathrm{SSC}, 0.5 \% \mathrm{SDS}$ at $68^{\circ} \mathrm{C}$ over a $50 \mathrm{~min}$ period. A final wash was performed in $0.1 \times \mathrm{SSC}, 0.5 \% \mathrm{SDS}$. The filters were dried under a red lamp for $30 \mathrm{~min}$; filters were then exposed to Kodak X-Omat film for autoradiography at $-70^{\circ} \mathrm{C}$ for $5-30 \mathrm{~h}$.

\section{RESULTS}

\section{Cloning of the tyrosinase gene}

Simplified restriction endonuclease cleavage maps of the cloning vectors pIJ37 and pIJ41 are shown in Fig. 1. pIJ37 carries the gene specifying neomycin resistance which was used for selection of transformants and has a unique $B c / I$ site which was employed for the initial cloning. pIJ41 contains the determinant specifying thiostrepton resistance (for selection of transformants); the BamHI site within the neomycin phosphotransferase (aph) gene was used in a subsequent cloning, making use of the insertional inactivation of neomycin resistance for clone recognition (Thompson et al., 1982b).

To clone the tyrosinase gene, $S$. antibioticus DNA was digested with $B c l$ I. DNA fragments were ligated to $B c l$-cleaved pIJ 37 or to BamHI-digested pIJ41. Ligation mixtures were used to transform protoplasts of the naturally $\mathrm{Mel}^{-} S$. lividans 1326 . After regeneration on R2YE plates, well-sporulated lawns were observed to contain numerous pocks (zones of growth inhibition) due to the $\mathrm{Ltz}^{+}$reaction associated with transfer of SLP1.2-derived plasmids into a plasmid-free host (Bibb et al., 1978). Spores were then replicated on to MMT plates containing tyrosine and either neomycin (pIJ37) or thiostrepton (pIJ41) for selection of drug-resistant transformants, in order to screen for expression of tyrosinase activity. Correspondance between plasmid-encoded phenotypes $\left(\mathrm{Ltz}^{+}\right.$reaction and patches of drug-resistant growth) indicated approximately 12000 transformants per experiment for each vector (pIJ37 or pIJ41); of these, one clone from each transformation synthesized a black, diffusible pigment, suggesting that it 

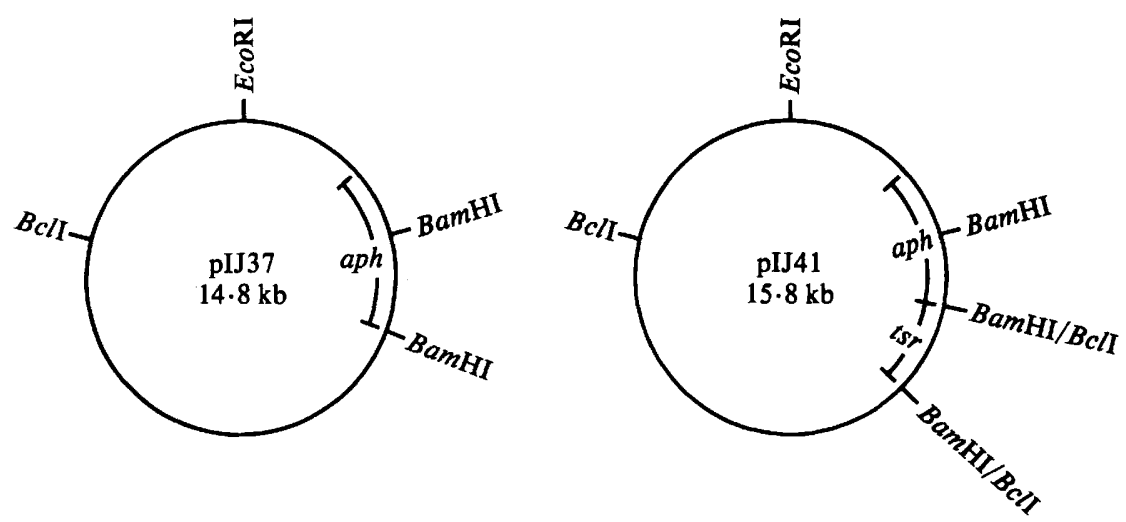

Fig. 1. Simplified restriction maps of pIJ37 and pIJ41. pIJ37 $(14.8 \mathrm{~kb})$ was derived by replacement in vitro of a segment of SLP1.2 DNA with DNA carrying the neomycin phosphotransferase (aph) determinant of $S$. fradiae; the thiostrepton resistance $(t s r)$ determinant $(1.0 \mathrm{~kb})$ of $S$. azureus was subsequently cloned into this plasmid to give pIJ41 $(15.8 \mathrm{~kb})$ (Thompson et al., 1982b).

had acquired the $\mathrm{Mel}^{+}$phenotype. The two $\mathrm{Mel}^{+}$clones were purified on selective media and characterized further.

Plasmid DNA (designated pIJ700 and pIJ701, respectively) was isolated from the two putative clones (strains 3129 and 3130) and used to transform protoplasts of $S$. lividans. All the resulting $\mathrm{Ltz}^{+}$transformants were also $\mathrm{Mel}^{+}$and resistant either to neomycin (pIJ700) or to thiostrepton (pIJ701). Moreover, strains harbouring pIJ701 were sensitive to neomycin. By contrast, insertion of the tyrosinase gene at the $B c / I$ site (pIJ37 $\rightarrow$ pIJ700) did not result in a detectable phenotypic change (except $\mathrm{Mel}^{+}$) in the plasmid vector.

Mating experiments were carried out between $S$. lividans 3129 (pIJ700) or S. lividans 3130 (pIJ701), which are streptomycin-sensitive prototrophs, and S. lividans TK64 (streptomycinresistant, proline-requiring). Spores were plated on MMT containing streptomycin and proline and then replica plated to neomycin or thiostrepton. The results confirmed that drug resistance (neomycin or thiostrepton) and the $\mathrm{Mel}^{+}$phenotype were transferred to TK64 at high frequency $(>50 \%)$.

$B c l$ I digestion of pIJ701 yielded two fragments which measured $5.6 \mathrm{~kb}$ and $>10 \mathrm{~kb}$, respectively. $B c l \mathrm{I}+H$ indIII double digests indicated that one cleavage site corresponded to the original $B c I I$ site of pIJ41 and the other was located about $1.55 \mathrm{~kb}$ from the expected position of the cloning site. Ligation of $B c l I$ fragments into the $B a m H I$ site of pIJ41 should result in a hybrid $B a m H I / B c l$ I sequence which is not recognized by either enzyme. The finding of a $B c l$ l cleavage site in the DNA inserted into the BamHI site of pIJ41 suggested that two $B c /$ fragments had been inserted or that a larger fragment of $S$. antibioticus DNA possessing an internal $B c l I$ site had been inserted during ligation. Since hybridization studies (see below) showed homology between the DNA inserts of pIJ700 or pIJ701, no further physical analysis of pIJ701 was made.

Restriction endonuclease analysis of pIJ700 was simpler to interpret since the hybrid plasmid had been constructed by insertion of $B c l I$ fragments into the $B c l I$ site of pIJ37. BclI digestion of PIJ700 resulted in two DNA fragments, one corresponding in size to the single $B c l$ I fragment of the vector $(14.8 \mathrm{~kb})$ and a smaller fragment $(1.55 \mathrm{~kb})$ which contained the tyrosinase gene.

Subcloning of the tyrosinase gene into a high copy number plasmid ( $p I J 350$ )

pIJ350, derived from the high copy number plasmid pIJ102, was employed for subcloning the tyrosinase gene from the low copy number plasmid, pIJ700. The plasmid vector $(4 \cdot 1 \mathrm{~kb})$ contains three $B c l I$ sites and carries the gene coding for thiostrepton resistance. pIJ350 is nonconjugative, is present at 40-300 copies per genome, and has a broad host-range (Kieser et al., 1982).

The vector was linearized by partial digestion with $B c l l$ and ligated with the fragments obtained from $B c l I$-cleaved pIJ700 (Fig. 2). After transformation and regeneration of $S$. lividans 

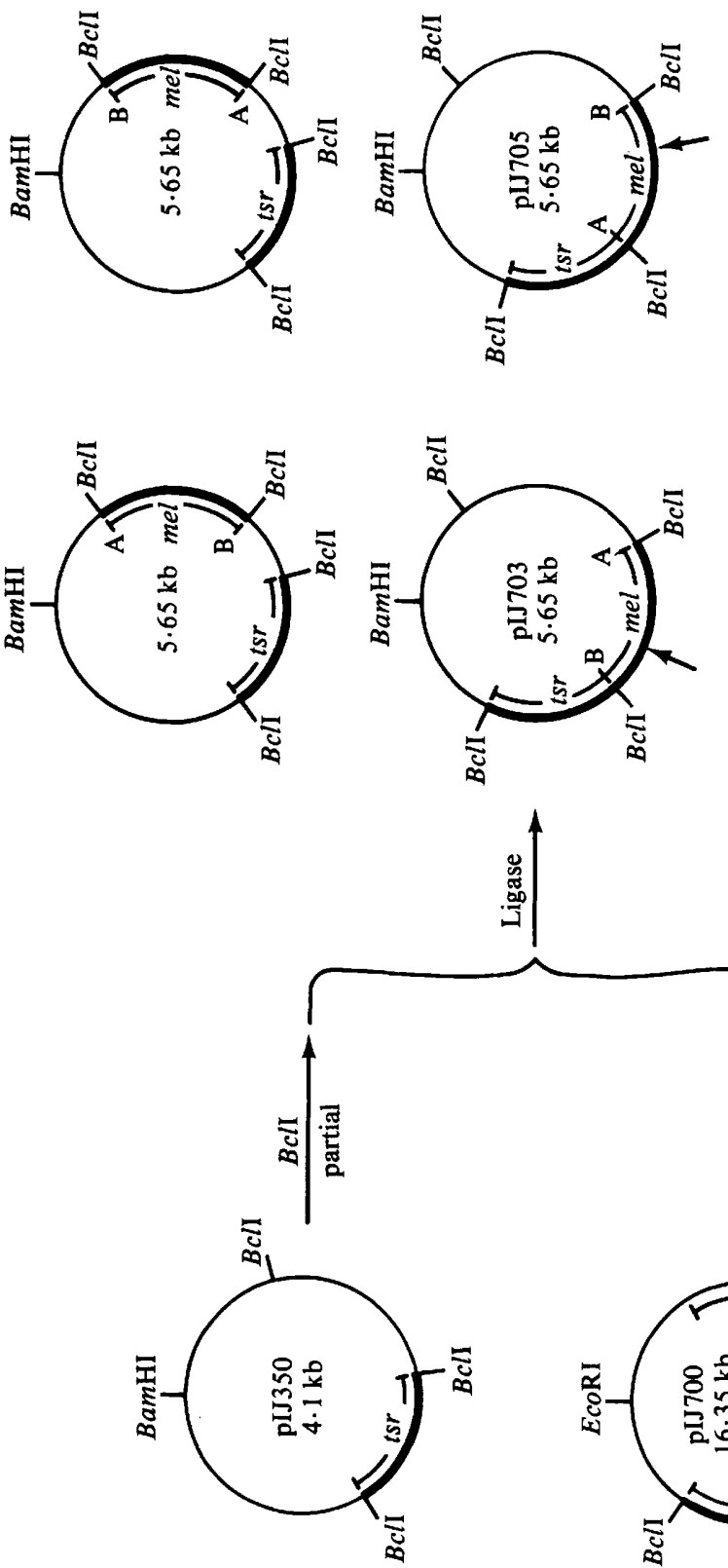
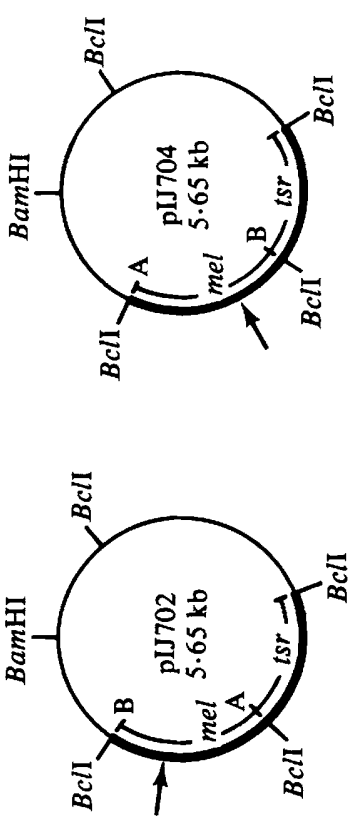

政

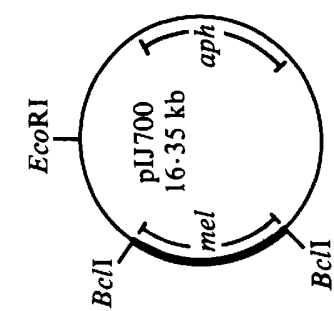

氧.

政

品文令

등형

을

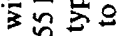

उ.

등

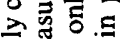

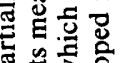

응

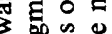

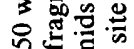

空品

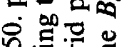

3

a

ㅇํำ응

증 ह

过

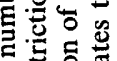

농요

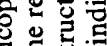

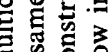

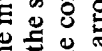

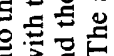

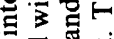

क्ष

……

졸

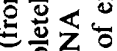

总穴

\& 8

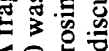

장인

을궁

范告

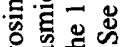

之焉

영요

哂范

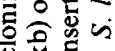

포.

守导

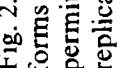


strain 1326 protoplasts, spores on regeneration plates were replica plated to MMT containing tyrosine and either neomycin or thiostrepton. $\mathrm{Mel}^{+}$, thiostrepton-resistant, neomycin-sensitive colonies were selected for further study after isolation and purification on selective media. The plasmid extracted from the various subclones transformed protoplasts of $S$. lividans 1326 to the same phenotype $\left(\mathrm{Mel}^{+}\right.$, thiostrepton resistance), was larger than the vector, pIJ350 $(5.65 \mathrm{~kb}$ versus $4.1 \mathrm{~kb})$ and digests of it contained a $B c l$ fragment $(1.55 \mathrm{~kb})$ in addition to the three from pIJ350.

Since pIJ350 contains three $B c l$ sites, following linearization by partial digestion with $B c l$, the tyrosinase DNA fragment could, in principle, be ligated into any one of these sites in either orientation. However, one of the sites is located in a region of the plasmid that is essential for plasmid replication; hence, insertion of foreign DNA into this site leads to the formation of plasmids that cannot be maintained successfully in $S$. lividans (Kieser et al., 1982). Double restriction digests $(B g l \mathrm{II}+P s t \mathrm{I}$ and $B g l \mathrm{II}+C l a \mathrm{I})$ were made of plasmid preparations derived from 17 independently-isolated strains. As described below, the tyrosinase DNA insert has a single asymmetric $B g l \mathrm{II}$ site and there are single sites for $P s t \mathrm{I}$ and $C l a \mathrm{I}$ in the vector, $\mathrm{pIJ} 350$. The sizes of the fragments generated in double digests (PstI $+B g l \mathrm{II} ; C l a \mathrm{I}+B g l \mathrm{II})$ agreed closely with previous data with respect to the location of restriction sites within pIJ350 and the tyrosinase DNA fragment (in pIJ700). Moreover, they showed that the four expected types of hybrid plasmids (Fig. 2) were represented amongst the 17 strains - with type specimens pIJ702 (strain 3131), pIJ703 (strain 3132), pIJ704 (strain 3133) and pIJ705 (strain 3134). The numbers of strains carrying the four types of plasmids were equal (4, 4, 5 and 4 , respectively).

\section{Restriction endonuclease cleavage map of pIJ702}

Single, double, and partial digests of pIJ702, combined with earlier maps of pIJ101 and its derivatives (Kieser et al., 1982) and the thiostrepton resistance gene (Thompson et al., 1982b) enabled us to derive the map shown in Fig. 3. The tyrosinase fragment $(1.55 \mathrm{~kb})$ possessed one cleavage site each for $S m a \mathrm{I}, S p h \mathrm{I}, B g l \mathrm{II}, S s t \mathrm{II}$ and $S s t \mathrm{I}$ and three sites for SalGI. There were no recognition sites for EcoRI, HindIII, XbaI, PstI, ClaI, KpnI or XhoI in the tyrosinase insert. A $S m a I$ digest located $S m a I$ site 21 relative to $S m a I$ site 2 . The positions of $S s t \mathrm{I}, S a l \mathrm{GI}, S s t \mathrm{II}, B g I \mathrm{II}$

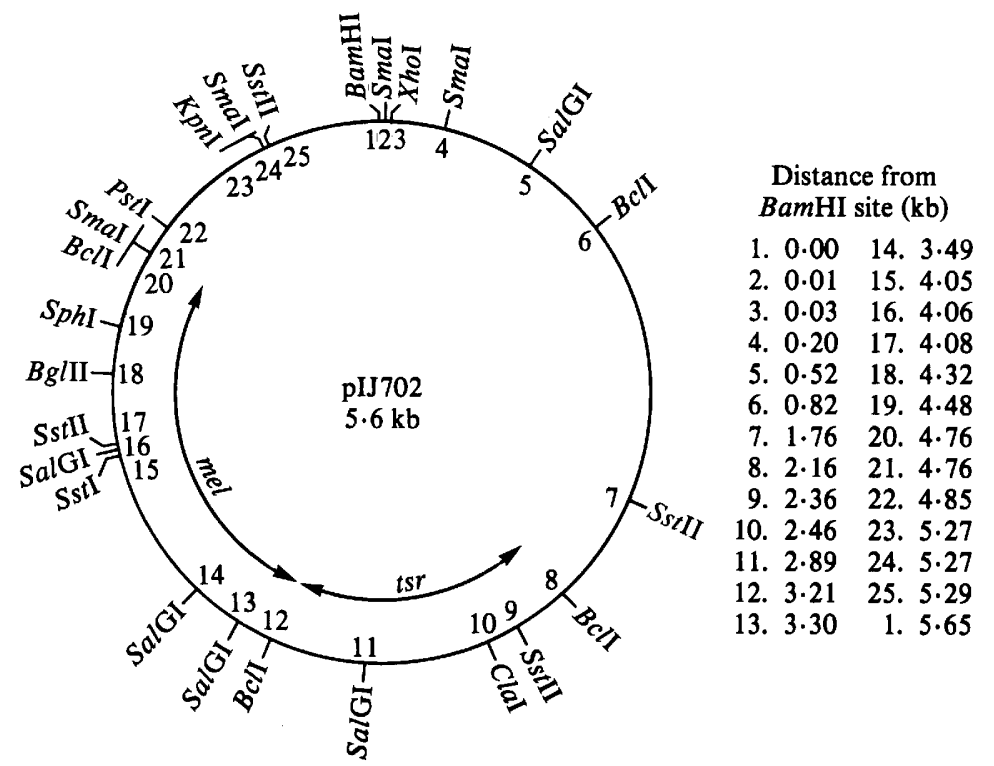

Fig. 3. Restriction map of pIJ702. The plasmid contains the thiostrepton-resistant determinant ( $t s r$ ) of $S$. azureus (Kieser et al., 1982) and the tyrosinase (mel) determinant of S. antibioticus. SstI, BgIII and $S p h \mathrm{I}$ are single sites that lie within the tyrosinase gene. 
and $S p h$ I sites at positions 15-19 were deduced from double digests using the above enzymes and PstI. Sites 15, 16 and 17 were located very near to one another and had to be ordered by a comparison of the smallest fragments generated by $B g l \mathrm{II}+S s t \mathrm{II}, B g l \mathrm{II}+\mathrm{SalGI}$ and $B g l \mathrm{II}+$ $S$ st I digests on a polyacrylamide gel. The order of the $S a l$ GI fragments was determined by a partial SalGI digest.

\section{Insertional inactivation of the $\mathrm{Mel}^{+}$phenotype}

The tyrosinase gene can be inactivated by insertion of DNA at the BglII, SstI or SphI sites (Fig. 4). SstI or BglII-generated S. griseus IMRU 3570 chromosomal fragments were ligated with pIJ702 cleaved with the same enzymes. After transformation and regeneration of protoplasts of $S$. lividans, $10 \mathrm{Mel}^{+}$and $10 \mathrm{Mel}^{-}$colonies from each transformation were purified. Mini-lysates derived from all $20 \mathrm{Mel}^{+}$colonies contained CCC plasmid DNA identical in size to pIJ 702; all $20 \mathrm{Mel}^{-}$colonies yielded CCC DNA larger than pIJ702. After cleavage with $B g I I I$ or Sst I, inserts of various sizes were observed by agarose gel electrophoresis. Religation and transformation restored the $\mathrm{Mel}^{+}$phenotype. Similarly, an SphI fragment containing the viomycin resistance gene (Thompson et al., 1982a) was used to probe the $S p h \mathrm{I}$ site in the tyrosinase DNA insert. pIJ702 and pIJ36 (a plasmid containing the viomycin resistance gene cloned into pBR322) were digested with $S p h \mathrm{I}$, ligated and used to transform S. lividans protoplasts. Viomycin-resistant $S$. lividans transformants were all thiostrepton-resistant and $\mathrm{Mel}^{-}$. Cleavage with $S p h \mathrm{I}$ and religation restored the $\mathrm{Mel}^{+}$phenotype.

\section{Hybridization studies}

${ }^{32}$ P-labelled pIJ700 and pIJ702 DNA were used as probes in Southern blotting experiments (Southern, 1975) with $B c l$ I-digested DNA from pIJ700, pIJ701 and S. antibioticus DNA. These studies confirmed that a $B c l$ I fragment corresponding to the $1.55 \mathrm{~kb}$ fragment cloned in pIJ700 is present in $S$. antibioticus DNA. It was also shown (with pIJ702 as the probe) that there is homology between the $1.55 \mathrm{~kb}$ fragment from pIJ700 and the larger DNA fragment $(>10 \mathrm{~kb})$ cleaved from pIJ701, indicating identity of the tyrosinase DNA cloned in pIJ700 and pIJ701 (Fig. 5).

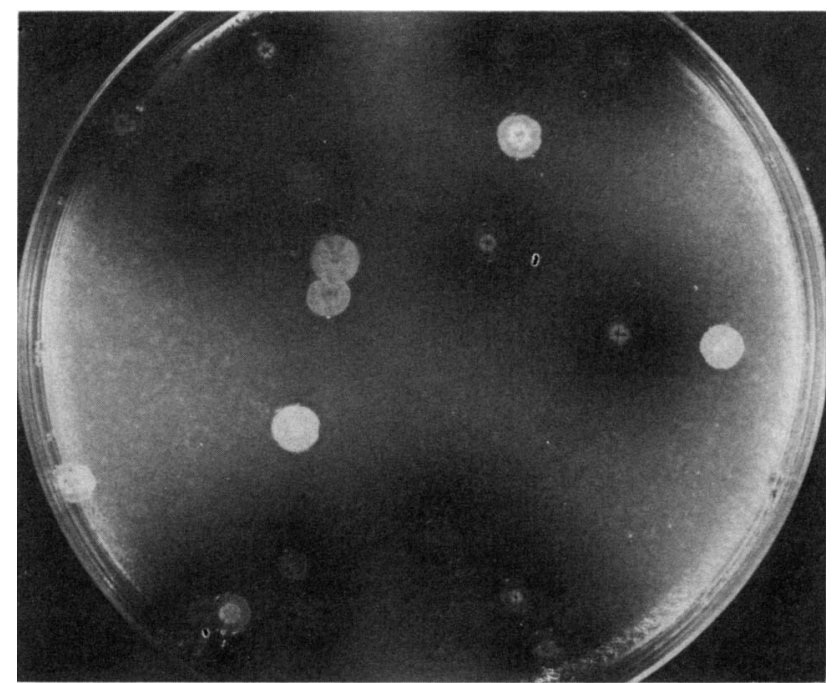

Fig. 4. Insertional inactivation of the $\mathrm{Mel}^{+}$phenotype. The tyrosinase gene can be inactivated by insertion of DNA at the $B g I I$, $S s t I$ or $S p h I$ sites. DNA fragments cleaved with $B g / I I$ were ligated with pIJ702 cleaved with the same enzyme. After transformation and regeneration of protoplasts, spores were plated on MMT containing thiostrepton and L-tyrosine. Colonies developing on the plate were thiostrepton-resistant and exhibited a $\mathrm{Mel}^{+}$or $\mathrm{Mel}^{-}$phenotype. 


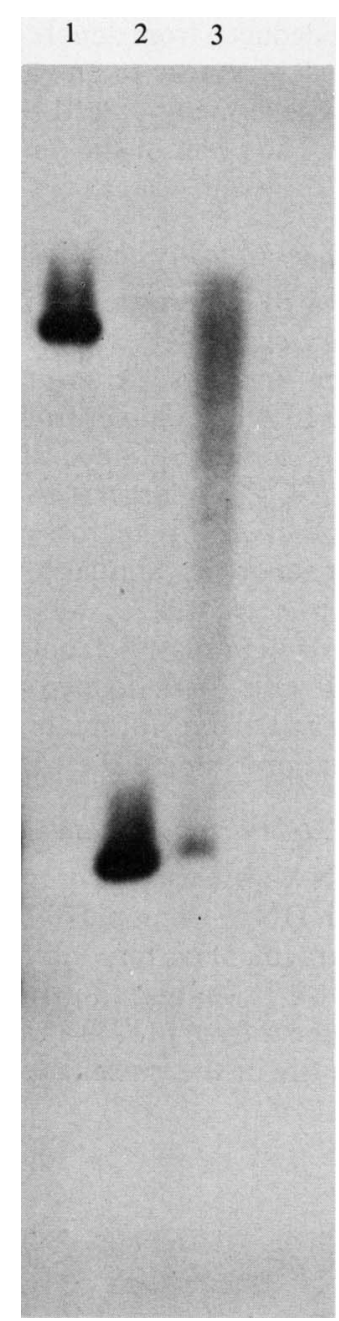

Fig. 5. Hybridization experiment. pIJ700, pIJ701 and $S$. antibioticus DNA were digested with $B c l$ and the DNA fragments were separated by agarose gel electrophoresis. After transfer to nitrocellulose filters (Southern, 1975) the DNA fragments were hybridized with nick-translated radiolabelled DNA prepared with pIJ702. The autoradiography revealed a single DNA fragment in $B c l$ digests of $S$. antibioticus DNA (track 3), and in pIJ700 (track 2), corresponding to the $1.55 \mathrm{~kb}$ fragment in $B c l$ cleaved $\mathrm{pIJ} 702$ (not shown). The hybridizing band in pIJ701 (track 1) indicates that the Mel fragments cloned in pIJ700 and pIJ701 are homologous.

\section{Host range of pIJ702}

PEG-mediated transformation of pIJ702 into protoplasts of seven other species of Streptomyces (S. coelicolor A3(2), S. griseus CUB 94, S. parvulus, S. albus G, S. vinaceus, $S$. acrimycini and $S$. clavuligerus), with selection for thiostrepton resistance was also observed. In the first six species, transformants were $\mathrm{Mel}^{+}$. With respect to $S$. clavuligerus transformants were $\mathrm{Mel}^{-}$, or occasionally weakly $\mathrm{Mel}^{+}$. However, transformation of $S$. lividans with plasmid DNA from $S$. clavuligerus yielded typical $\mathrm{Mel}^{+}$transformants; thus, lack of expression of the $\mathrm{Mel}^{+}$ phenotype in $S$. clavuligerus was not due to a permanent alteration in the tyrosinase gene.

\section{Biochemical investigations}

Strains 3129 to 3134 of $S$. lividans harbouring the recombinant plasmids pIJ700 to pIJ705, respectively, were found to possess an inducible tyrosinase activity (Table 1). Upon addition of 
tryptose to GYM medium, there was increased synthesis of the enzyme, although at a slower rate than that observed with $S$. antibioticus. Experiments with the $\mathrm{Mel}^{+}$strains of S. lividans revealed that the enzyme was formed intracellularly, but it was not secreted to any significant extent (Fig. 6 ). The level of activity of the intracellular tyrosinase (induced cells) appeared to be the same in $S$. antibioticus and in strain 3130 of S. lividans carrying the low-copy plasmid, pIJ701. There was a higher level of enzyme activity in the strains (induced with tryptose) with the high-copy plasmids (2.5- to 36-fold greater). Additional investigations relating to expression of the tyrosinase gene are currently under investigation.

Table 1. Expression of tyrosinase activity (intracellular) in S. antibioticus and in S. lividans strains harbouring recombinant plasmids

\begin{tabular}{|c|c|c|c|c|c|c|}
\hline \multirow[b]{2}{*}{ Organism } & \multirow[b]{2}{*}{ Plasmid } & \multicolumn{2}{|c|}{$\begin{array}{l}\text { Tyrosinase specific activity } \\
\left.\text { [units (mg protein })^{-1}\right]\end{array}$} & \multirow{2}{*}{$\begin{array}{l}\text { Ratio of } \\
\text { induced/ } \\
\text { uninduced }\end{array}$} & \multicolumn{2}{|c|}{ Relative activity } \\
\hline & & Uninduced & Induced & & Uninduced & Induced \\
\hline antibioticus & - & 0.015 & 0.462 & $30 \cdot 8$ & $1 \cdot 0$ & $1 \cdot 0$ \\
\hline lividans 3129 & pIJ700 & $0 \cdot 008$ & $0 \cdot 184$ & $23 \cdot 0$ & 0.5 & $0 \cdot 4$ \\
\hline lividans 3130 & pIJ701 & 0.064 & 0.466 & $7 \cdot 3$ & $4 \cdot 3$ & $1 \cdot 0$ \\
\hline lividans 3131 & pIJ702 & $0 \cdot 286$ & $2 \cdot 368$ & $8 \cdot 3$ & 19 & $5 \cdot 2$ \\
\hline lividans 3132 & pIJ703 & 1.803 & $16 \cdot 600$ & $9 \cdot 2$ & 120 & $36 \cdot 1$ \\
\hline lividans 3133 & pIJ704 & 0.636 & $3 \cdot 812$ & $6 \cdot 0$ & 42 & $8 \cdot 3$ \\
\hline lividans 3134 & pIJ705 & $0 \cdot 129$ & $1 \cdot 194$ & $9 \cdot 3$ & 8.6 & $2 \cdot 6$ \\
\hline
\end{tabular}
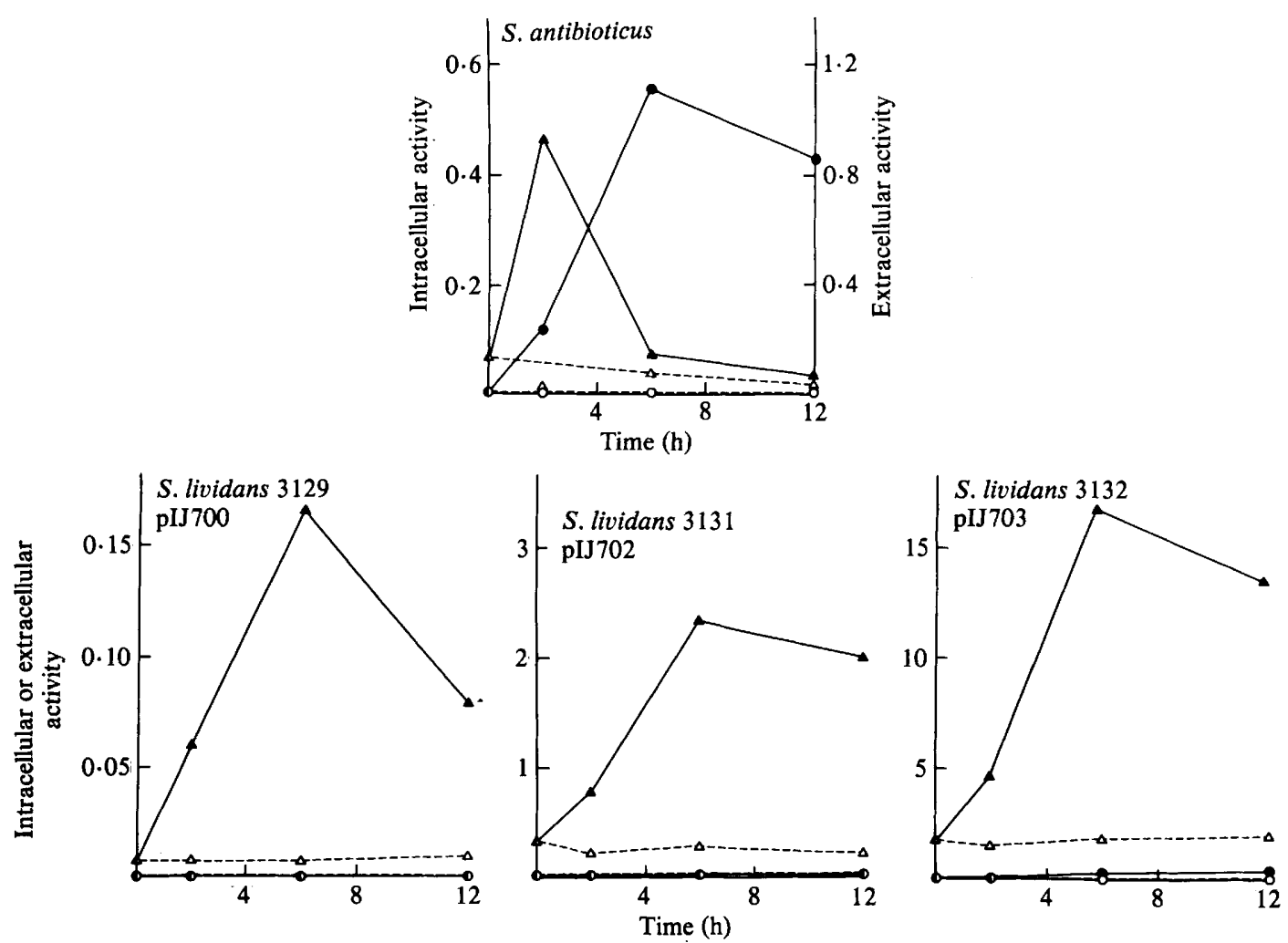

Fig. 6. Synthesis of tyrosinase activity of $S$. antibioticus and clones of $S$. lividans (harbouring the plasmid pIJ700, pIJ702 or pIJ 703) in GYM medium with or without tryptose $\left(10 \mathrm{mg} \mathrm{ml}^{-1}\right)$. Tryptose was added to $20 \mathrm{~h}$ cultures of $S$. antibioticus and to $36 \mathrm{~h}$ cultures of $S$. lividans. Mycelium was harvested at $0,2,6$, and $12 \mathrm{~h}$ post-induction with tryptose. Intracellular tyrosinase activity $(\boldsymbol{\Lambda}, \Delta)$ is expressed as units $(\mathrm{mg}$ protein $)^{-1}$; extracellular tyrosinase activity $(0, O)$ is expressed as units $\mathrm{ml}^{-1}$. Solid line, tryptose present; broken line, tryptose absent. 


\section{DISCUSSION}

It is likely that the $1.55 \mathrm{~kb} \mathrm{Bcll}$ fragment of $S$. antibioticus DNA carries natural initiation signals for transcription and translation of the tyrosinase gene since enzyme activity was well expressed, not only in the $B c / I$ site in the primary clone (pIJ700) but also, in both orientations, in the two available $B c l I$ sites of pIJ350. Moreover, tyrosinase activity was inducible in strains carrying any of the six hybrid plasmids, as in the $S$. antibioticus parent, suggesting that regulatory sequences had been cloned together with the structural gene. However, in contrast to the translocation of the enzyme in S. antibioticus, tyrosinase remained largely intracellular in the cloned strains. It is possible that a mechanism(s) required for cleavage of a tyrosinase 'signal sequence' (Davis \& Tai, 1980) or for post-translational modification of the intracellular enzyme for secretion (Lai et al., 1981; Nielsen et al., 1981; Nielsen \& Lampen, 1982) is absent in $S$. lividans. In an analogous study Robbins et al. (1981), using as heterologous host Escherichia coli, cloned the structural gene for endoglycosidase $\mathrm{H}$ from $S$. plicatus DNA. The intracellular form of the endoglycosidase synthesized by $E$. coli was reported to have a molecular weight of approximately 30000 , which contrasts with the secreted enzyme $(27000 \mathrm{~mol}$. wt) made by $S$. plicatus. Further investigations employing both $S$. antibioticus and the cloned strains of $S$. lividans should prove useful for elucidating the control mechanism of tyrosinase synthesis and its secretion.

The $S$. antibioticus gene coding for tyrosinase is a useful component of cloning vectors derived from pIJ101. The cloned $B c l$ fragment has single $B g l \mathrm{II}, S p h \mathrm{I}$ and $S s t \mathrm{I}$ sites; thus, insertion of foreign DNA into one of these sites results in insertional inactivation of the tyrosinase gene. As a consequence, white instead of brown or black host colonies develop. The pIJ702 plasmid (at the $B g I I I$ or SstI sites) has already proved useful in the isolation of clones carrying components of the glycerol utilization $(g y l)$ operon (E. T. Seno, personal communication) and of the undecylprodigiosin gene cluster (J. S. Feitelson, personal communication) of $S$. coelicolor. Further, the presence of the tyrosinase promoter might permit expression of genes (cloned into the $B g I \mathrm{II}, S s t \mathrm{I}$ or $S p h \mathrm{I}$ sites) that lack a functional promoter sequence. Whether the potential exportability of the tyrosinase system can be utilized in order to achieve secretion of products of cloned genes remains to be established.

Amplification of some products of cloned genes is one of the potential advantages of a highcopy number plasmid, and this appears to be the case for tyrosinase activity. Thus, strains of $S$. lividans harbouring a high-copy number plasmid carrying the tyrosinase gene (pIJ702 to pIJ705) have higher tyrosinase activity (2.5- to 36 -fold) than those carrying a low-copy number plasmid (pIJ700, pIJ701) or S. antibioticus itself. However, further work will be needed to establish the reason(s) why a strict dosage effect on the level of tyrosinase activity was not observed in strains carrying pIJ702 to pIJ705. Since the site of insertion and/or the orientation of the tyrosinase DNA fragment in pIJ350 greatly influence gene expression, proximity to a potent plasmid promoter or terminator may be important. However, physiological or regulatory factors, such as growth rate, medium $\mathrm{pH}$, availability and utilization of a substrate (or inducer), amount of repressor formed, etc., may also have an effect. It will be of interest to transform $\mathrm{Mel}^{+}$and $\mathrm{Mel}^{-}$ strains of $S$. antibioticus with the recombinant plasmids to investigate the influence of both chromosomal- and plasmid-specified determinants upon enzyme synthesis.

Melanin production is a property of sporadic occurrence in many prokaryotes and eukaryotes. The cloned tyrosinase gene of $S$. antibioticus, therefore, may be useful to investigate questions concerning possible evolutionary divergence or convergence of the corresponding gene and enzyme in other organisms. For example, when used as a DNA probe in Southern transfer experiments, it has allowed the recognition of closely-related DNA in other $\mathrm{Mel}^{+}$Steptomyces species, but not in $\mathrm{Mel}^{-}$strains (H. Schrempf, E. Katz and D. A. Hopwood, unpublished results). It will, therefore, be useful in elucidating the nature of the genetic instability involving melanin production which has been observed in several of the Streptomyces species containing related sequences. Gregory \& Shyu (1961) and Gregory \& Huang (1964) postulated plasmid determination of the $\mathrm{Mel}^{+}$phenotype. Recent evidence suggests that the genes for synthesis and secretion of tyrosinase activity are chromosomal in S. glaucescens (Crameri et al., 1982). The cloned tyrosinase gene ( $S$. antibioticus) has been also used to establish that the frequent $\mathrm{Mel}^{-}$ 
variants of $S$. reticuli arise after deletion of DNA, including the tyrosinase gene, from the chromosome $(H$. Schrempf, unpublished results). It is also of interest to note that the first reaction in the biosynthesis of the propylhygric acid moiety of the antibiotic lincomycin is the conversion of L-tyrosine to DOPA (Witz et al., 1971; Michalik et al., 1975). The similarity of this enzyme-catalysed reaction to the one carried out by tyrosinase suggests that the cloning of the relevant gene from $S$. lincolnensis DNA would be readily obtainable. Further, isolation of the eukaryotic gene(s) specifying tyrosinase synthesis (Fling et al., 1963; Pomerantz, 1963; Ottolenghi-Nightingale, 1969; Burnett, 1971) may also be feasible, using similar selection procedures.

We wish to thank Dr Hildgund Schrempf for her expert advice and participation in the hybridization studies and Dr José Gil and Ms Judith Ward for contributions to the insertional inactivation experiment. We are grateful to Dr Tobias Kieser for his advice and suggestions throughout the investigation and Dr Keith Chater for his helpful comments on the manuscript.

\section{REFERENCES}

BaumanN, R. \& Kocher, H. P. (1976). Genetics of Streptomyces glaucescens and regulation of melanin production. In 2nd International Symposium on Genetics of Industrial Microorganisms, pp. 535-551. Edited by K. D. Macdonald. London: Academic Press.

BaumanN, R., EtTlinger, L., Hütter, R \& KoCher, H. P. (1976). Control of melanin formation in Streptomyces glaucescens. In Actinomycetes: the Boundary Microorganisms, pp. 55-63. Edited by T. Arai. Tokyo: Toppan Co.

Bibb, M. J., Freeman, R. F. \& Hopwood, D. A. (1977). Physical and genetical characterisation of a second sex factor, SCP2, for Streptomyces coelicolor A3(2). Molecular and General Genetics 154, 155-166.

BibB, M. J., Ward, J. M. \& Hopwood, D. A. (1978). Transformation of plasmid DNA into Streptomyces at high frequency. Nature, London 274, 398-400.

Bibi, M. J., Schottel, J. L. \& COHEN, S. N. (1980). A DNA cloning system for interspecies gene transfer in antibiotic-producing Streptomyces. Nature, London 284, 526-531.

Birnbolm, H. C. \& Doly, J. (1979). A rapid alkaline extraction procedure for screening recombinant plasmid DNA. Nucleic Acids Research 7, 1513-1523.

Bouchilloux, S., McMahill, P. \& Mason, H. S. (1963). The multiple forms of mushroom tyrosinase. Purification and molecular properties of the enzymes. Journal of Biological Chemistry 238, 16991707.

Bull, A. T. \& CARTER, B. L. A. (1973). The isolation of tyrosinase from Aspergillus nidulans, its kinetic and molecular properties and some consideration of its activity in vivo. Journal of General Microbiology 75, 61-73.

BURNETT, J. B. (1971). The tyrosinases of mouse melanoma. Isolation and molecular properties. Journal of Biological Chemistry 246, 3079-3091.

Chater, K. F., Hopwood, D. A., Kieser, T. \& Thompson, C. J. (1982). Gene cloning in Streptomyces. Current Topics in Microbiology and Immunology 96, 69-95.

Crameri, R., Ettlinger, L., Hütter, R., Lerch, K., Suter, M. A. \& Vetterli, J. A. (1982). Secretion of tyrosinase in Streptomyces glaucescens. Journal of General Microbiology 128, 371-379.
Davis, B. D. \& TAI, P. C. (1980). The mechanism of protein secretion across membranes. Nature, London 283, 433-438.

DenhaRdT, D. T. (1966). A membrane-filter technique for the detection of complementary DNA. Biochemical and Biophysical Research Communications 23, 641-646.

Fling, M., Horowitz, N. H. \& Heinemann, S. F. (1963). The isolation and properties of crystalline tyrosinase from Neurospora. Journal of Biological Chemistry 238, 2045-2053.

Gregory, K. F. \& Huang, J. C. C. (1964). Tyrosinase inheritance in Streptomyces scabies. I. Genetic recombination. Journal of Bacteriology 87, 12811286.

Gregory, K. F. \& ShYU, W.-J. (1961). Apparent cytoplasmic inheritance of tyrosinase competence in Streptomyces scabies. Nature, London 191, 465-467.

Hopwood, D. A. (1967). Genetic analysis and genome structure in Streptomyces coelicolor. Bacteriological Reviews 31, 373-403.

Karlson, P., Mergenhagen, D. \& Sekeris, C. E. (1964). Zum Tyrosinstoffwechsel der Insekten, XV. Weitere Untersuchungen über das o-Diphenyloxydase-System von Calliophora erythrocephala. HoppeSeyler's Zeitschrift für physiologische Chemie 338, 4250.

KIESER, T. (1982). DNAGEL: a computer program for determining DNA fragment sizes using a small computer equipped with a graphics tablet. Experientia 38, 1381 .

Kieser, T., EtTlinger, L. \& HÜtTER, R. (1981). Mutants of Streptomyces glaucescens constitutive for tyrosinase synthesis. In Genetics of the Actinomycetales, pp. 59-60. Edited by K. P. Schaal \& G. Pulverer. Gustav Fischer: Stuttgart.

KIESER, T., HopwOOD, D. A., WRIGHT, H. M. \& THOMPSON, C. J. (1982). pIJ101, a multi-copy broad host-range Streptomyces plasmid : functional analysis and development of DNA cloning vectors. Molecular and General Genetics 185, 223-238.

KüsTER, E. (1976). Chromogenicity of actinomycetes. In Actinomycetes: the Boundary Microorganisms, pp. 43-54. Edited by T. Arai. Tokyo: Toppan Co.

LaI, J.-S., SARVAS, M., Brammer, W. J., Neugebauer, K. \& Wu, W. C. (1981). Bacillus licheniformis 
penicillinase synthesized in Escherichia coli contains covalently linked fatty acid and glyceride. Proceedings of the National Academy of Sciences of the United States of America 78, 3506-3510.

LeRCH, K. \& EtTlinger, L. (1972). Purification and characterization of a tyrosinase from Streptomyces glaucescens. European Journal of Biochemistry 31, 427-437.

Michalik, J., Emilianowicz-Czerska, W., SwitalSKI, L. \& RACZYNSKA-BojanOWSKA, K. (1975). Monophenol monooxygenase and lincomycin biosynthesis in Streptomyces lincolnensis. Antimicrobial Agents and Chemotherapy 8, 526-531.

NaKamura, T. \& Sho, S. (1964). Studies on silkworm tyrosinase. Journal of Biochemistry 55, 510-515.

Nielsen, J. B. K. \& LAMPEN, J. O. (1982). Membranebound penicillinases in gram-positive bacteria. Journal of Biological Chemistry 257, 4490-4495.

Nielsen, J. B. K., Caufield, M. P. \& Lampen, J. O. (1981). Lipoprotein nature of Bacillus licheniformis membrane penicillinase. Proceedings of the National Academy of Sciences of the United States of America 78, 3511-3515.

OKanishi, M., SuzukI, K. \& UmezaWa, H. (1974). Formation and reversion of Streptomyces protoplasts: cultural conditions and morphological study. Journal of General Microbiology 80, 389-400.

OTTOLENGHI-NIGHTINGALE, E. (1969). Induction of melanin synthesis in albino mouse skin by DNA from pigmented mice. Proceedings of the National Academy of Sciences of the United States of America 64, 184-189.

Pomerantz, S. H. (1963). Separation, purification, and properties of two tyrosinases from hamster melanoma. Journal of Biological Chemistry 238, 23512357

Pomerantz, S. H. \& Murthy, V. V. (1974). Purification and properties of tyrosinases from Vibrio tyrosinaticus. Archives of Biochemistry and Biophyscis 160, 73-82.
Rigby, P. W. J., Dieckmann, M., Rhodes, C. \& Berg, P. (1977). Labelling deoxyribonucleic acid to high specific activity in vitro by nick-translation with DNA-polymerase I. Journal of Molecular Biology 113, 237-251.

Robb, D. A., Mapson, L. W. \& Swain, T. (1965). On the heterogeneity of the tyrosinase of broad bean (Vicia faba L.). Phytochemistry 4, 731-740.

Robilns, P. W., WIRTH, D. F. \& Hering, C. (1981). Expression of the Streptomyces enzyme endoglycosidase $\mathrm{H}$ in Escherichia coli. Journal of Biological Chemistry 256, 10640-10644.

Southern, E. M. (1975). Detection of specific sequences among DNA fragments separated on agarose gel electrophoresis. Journal of Molecular Biology 98, 503-517.

SuAREZ, J. E. \& Chater, K. F. (1980). DNA cloning in Streptomyces: a bi-functional replicon comprising pBR322 inserted into a Streptomyces phage. Nature, London 286, 527-529.

Thompson, C. J., Ward, J. M. \& Horwood, D. A. (1980). DNA cloning in Streptomyces: resistance genes from antibiotic producing species. Nature, London 286, 525-527.

ThOMPSON, C. J., Ward, J. M. \& Hopwood, D. A. (1982a). Cloning of antibiotic resistance and nutritional genes from antibiotic producing species. Journal of Bacteriology 151, 668-677.

ThOMPSON, C. J., KIESER, T., WARD, J. M. \& Hopwood, D. A. $(1982 \mathrm{~b})$. Physical analysis of antibiotic-resistance genes from Streptomyces and their use in vector construction. Gene 20, 51-62.

Vaughan, P. F. T. \& ButT, V. S. (1970). The action of $O$-dihydric phenols in the hydroxylation of $p$ coumaric acid by a phenolase from leaves of spinach beet (Beta vulgaris L.). Biochemical Journal 119, 89 94.

Witz, D. F., Hessler, E. J. \& Miller, T. L. (1971). Bioconversion of tyrosine into the propylhygric acid moiety of lincomycin. Biochemistry 10, 1128-1132. 